\title{
Identification of Pseudomonas cepacia Burkholder and Its Synonymy with Pseudomonas kingii Jonsson
}

\author{
J. J. S. SNELL, L. R. HILL, S. P. LAPAGE, and M. A. CURTIS \\ National Collection of Type Cultures, and Computer Trials Department, \\ Central Public Health Laboratory, Colindale Avenue, London, NW9 5HT, England
}

\begin{abstract}
Thirty-five strains of Pseudomonas cepacia Burkholder, isolated over the last 6 years, were compared with three EO-1 strains, two strains of $P$. multivorans Stanier et al, and the type strains of $P$. cepacia and $P$. kingii Jonsson, the name of the latter having been given to the EO-1 group. The strains were examined in a range of morphological, biochemical, and carbon substrate utilization tests, and, for selected strains, by electron microscopy, deoxyribonucleic acid base composition, serotyping, and phage typing. From the results of these tests, $P$. kingii Jonsson 1970 (EO-1 group) is considered a later subjective synonym of $P$. cepacia Burkholder 1950 ( $P$. multivorans). The outstanding property of $P$. cepacia is its nutritional versatility, which is reflected in the large number of carbohydrates from which acid is produced by this organism. A table is given for differentiating $P$. cepacia from $P$. pseudomallei, $P$. mallei, $P$. aeruginosa, $P$. fluorescens, $P$. stutzeri, and $P$. maltophilia.
\end{abstract}

In recent years, a number of papers have appeared concerning a nonfluorescent, nutritionally versatile pseudomonad variously called Pseudomonas cepacia Burkholder 1950, P. multivorans Stanier, Palleroni and Doudoroff 1966, P. kingii Jonsson 1970, or EO-1 group ("eugonic oxidizers, group 1"; King, 18). Ballard et al. (1) established the synonymy of $P$. multivorans with Burkholder's (4) earlierdescribed $P$. cepacia, a phytopathogenic species, the latter name having nomenclatural priority. Other workers have noted the similarity between $P$. cepacia and $P$. multivorans (37) and between these and EO-1 strains, later called $P$. kingii by Jonsson $(17$; see also $8,9,23,33)$. However, no formal proposal appears to have been made establishing $P$. kingii (EO-1) as another junior synonym of $P$. cepacia.

During the last 6 years we have identified 35 strains as $P$. cepacia. These strains, and two strains of $P$. multivorans, were found to be very similar to three representative EO-1 strains, in agreement with above-quoted authors. The same range of tests used in characterizing the $P$. cepacia strains was then applied to the type strain of $P$. cepacia (ATCC 25416; NCTC 10743) and the type strain of $P$. kingii (ATCC 25609; NCTC 10744) to establish whether the latter is a synonym of $P$. cepacia.
$P$. cepacia is of considerable clinical importance. Under one or other of the abovementioned names, it is referred to by Hardy, Ederer, and Matsen (12) and by Phillips et al. (32) as a low-grade pathogen, but its ability to contaminate and perhaps grow in certain disinfectants in current use in hospitals (2) makes it a potentially dangerous organism. Reports of the isolation of this organism (again, variously named) from the hospital environment and from pathological material have been made by a number of authors $(2,3,7-9,12$, $23,27,32,42,44,48)$. Both Jonsson (17) and Hugh (15) listed many sources from which this organism has been isolated.

In addition to establishing formally the synonymy of $P$. kingii with $P$. cepacia, the present paper gives a full characterization of $P$. cepacia to assist differentiation from other pseudonomads likely to be encountered from hospital sources and adds to the clinical documentation of this pathogen.

\section{MATERIALS AND METHODS}

Organisms. Thirty-five field strains of $P$. cepacia were examined and compared with three EO-1 strains (see Table 1) and with the following NCTC strains: NCTC 10661 (strain Hayward 8; ATCC 17759; Stanier's 
TABLE 1. Field strains used in the present work

\begin{tabular}{|c|c|c|c|c|}
\hline $\begin{array}{l}\text { No. of } \\
\text { strains }\end{array}$ & $\begin{array}{c}\text { Strain } \\
\text { designations }\end{array}$ & Received from & $\begin{array}{l}\text { Source or } \\
\text { clinical } \\
\text { condition }\end{array}$ & References \\
\hline 1 & A $73 / 66$ & R. L. McCorry, Belfast, UK & Blood culture & \\
\hline 7 & A28-34/69 & K. J. Stokes, Surrey, UK & Infected wounds & \\
\hline 4 & A $38-41 / 69$ & K. J. Stokes, Surrey, UK & Savlon & 2 \\
\hline 2 & A46-47/69 & K. J. Stokes, Surrey, UK & Waters & \\
\hline 4 & A64-67/69 & D. C. Jenkins, Kansas, USA & Urines & \\
\hline 1 & $\mathrm{~A} 102 / 69^{a}$ & R. E. Weaver, Atlanta, USA & Urine & \\
\hline 1 & $\mathrm{~A} 103 / 69^{a}$ & R. E. Weaver, Atlanta, USA & Detergicide & \\
\hline 1 & A $104 / 69^{a}$ & R. E. Weaver, Atlanta, USA & Pneumonitis & 7 \\
\hline 1 & $\mathrm{~A} 107 / 69^{b}$ & R. E. Weaver, Atlanta, USA & Endocarditis & 11 \\
\hline 3 & A61-62/70, A115/70 & I. Phillips, Lond on, UK & Blood cultures & \\
\hline 4 & $\begin{array}{l}\text { A99/70, A109/70, A111/70 } \\
\text { A113/70 }\end{array}$ & I. Phillips, London, UK & Respirators & 32 \\
\hline 1 & A98/70 & E. Lockey, London, UK & Blood culture & \\
\hline 1 & A $105 / 70$ & E. Lockey, London, UK & Intravenous fluid & \\
\hline 2 & A104/70, A116/70 & E. Lockey, London, UK & Cetavlon & \\
\hline 1 & A117/70 & E. Lockey, London, UK & Savlon & \\
\hline 4 & A106-108/70, A136/70 & D. C. E. Speller, Bristol, UK & Blood cultures & 42 \\
\hline
\end{tabular}

${ }^{a}$ Received as EO-1 strains.

$b$ Received as a IVd strain.

number 382), the type strain designated for $P$. multivorans by Stanier et al. (43); NCTC 10734 (strain Sneath B269, TI; ATCC 17774; Stanier 425), received from P. H. A. Sneath ("Chromobacterium ianthinum," Sneath $[40,41])$ and identified as $P$. multivorans by Stanier et al. (43); NCTC 10743 (strain Stanier 717; ATCC 25416), the type strain designated for $P$. cepacia by Ballard et al. (1); NCTC 10744 (strain Jonsson A977, ATCC 25609), the type strain designated for $P$. king ii by Jonsson (17).

The episodes from which most of the field strains were obtained are described in the references included in Table 1. The following episodes have not been previously described: (i) One strain from R. L. McCorry, isolated from a blood culture of a hydrocephalic child in whom a Wade valve had been inserted. (ii) Four strains from D. C. Jenkins, isolated from urine and sent to us for identification with no further details. (iii) Five strains from E. Lockey, from a 42-year-old male who was admitted to hospital with a history of mild chest pain of 2 years' duration, which became more severe. Continuous intravenous infusion of heparin was started, but in a few days the patient developed a temperature of $104 \mathrm{~F}$ with rigors. A strain of $P$. cepacia was isolated from a blood culture taken at this time. After initial failure with gentamicin, Septrin was administered, and the patient became apyrexial. Subsequently, further strains of $P$. cepacia were isolated twice from Cetavlon (centrimonium bromide) and from Savlon (chlorhexidine and cetrimide) in use in the ward, and from intravenous fluid being given to another patient.

A summary of the sources of the strains examined, excluding the NCTC strains, is given in Table 2.

Bacteriological investigations. Biochemical tests in routine use in the National Collection of Type Cultures (NCTC) and Computer Trials Department
TABLE 2. Summary of the sources of the field strains

\begin{tabular}{|c|c|c|c|}
\hline \multirow[b]{2}{*}{ Source } & \multicolumn{2}{|c|}{ Origin } & \multirow[b]{2}{*}{ Totals } \\
\hline & UK & USA & \\
\hline \multirow{9}{*}{$\begin{array}{l}\text { Human } \\
\text { Blood cultures } \\
\text { Wounds } \\
\text { Urine } \\
\text { Miscellaneous } \\
\text { Disinfectants } \\
\text { Water } \\
\text { Respirators } \\
\text { Drip-line }\end{array}$} & & & \\
\hline & 9 & 2 & \\
\hline & 7 & & 23 \\
\hline & & 5 & \\
\hline & & & \\
\hline & 7 & 1 & \\
\hline & 2 & & 15 \\
\hline & 4 & & 15 \\
\hline & 1 & & \\
\hline Totals & 30 & 8 & 38 \\
\hline
\end{tabular}

were used for bacteriological investigations. Most of these tests were described by Cowan and Steel (5). The tests used are listed in Table 3 and comprise the same range of tests used by Lapage, Hill, and Reeve (22), with the following changes or additions. Nitrate reduction aerobically and anaerobically was tested by Crosby's (6) modification of the GriessIlosvay method, in which 1-naphthylamine-7-sulfonic acid (Cleve's acid) replaces 1-naphthylamine; selenite reduction (32); Tween 80 hydrolysis (38); hydrolysis of esculin (5) and tyrosine (10); Richard's (36) method of detecting breakdown of lysine and ornithine as well as Møller's (28) method; and growth on deoxycholate agar and serum liquefaction (5). In addition, carbon substrate utilization tests (43) were carried out on 30 of the strains, using the chemically defined medium of Owens and Keddie (31) and with the carbon substrates (listed in Table 4) at a final concentration of $0.2 \%(\mathrm{w} / \mathrm{v})$. 
TABLE 3. Characters of the field strains of Pseudomonas cepacia compared with EO-I strains and the four NCTC strains

\begin{tabular}{|c|c|c|c|c|c|c|c|}
\hline \multirow[b]{2}{*}{ Characters } & \multirow{2}{*}{$\begin{array}{l}\text { Field } \\
\text { strains }\end{array}$} & \multirow{2}{*}{$\begin{array}{c}\text { EO-1 } \\
\text { strains }\end{array}$} & \multicolumn{4}{|c|}{ NCTC strains } & \multirow{2}{*}{$\begin{array}{l}\text { Composite } \\
\text { result for } \\
P . \text { cepacia }^{b}\end{array}$} \\
\hline & & & 10661 & 10734 & 10743 & 10744 & \\
\hline Motility & $31 / 35$ & $3 / 3$ & + & + & + & + & + \\
\hline$>1$ Flagellum/cell. & $17 / 17$ & $3 / 3$ & + & NT & NT & NT & + \\
\hline Growth on nutrient agar, at $5 \mathrm{C}$ & $0 / 35$ & $0 / 3$ & - & - & - & - & - \\
\hline Growth on nutrient agar, at $44 \mathrm{C}$ & $13 / 35$ & $3 / 3$ & - & - & - & - & $d$ \\
\hline Growth on MacConkey agar . . . . . . . & $29 / 29$ & $3 / 3$ & + & + & + & + & + \\
\hline Growth on deoxycholate agar $\ldots \ldots$ & $27 / 34$ & $1 / 3$ & + & - & NT & NT & $d$ \\
\hline $\begin{array}{l}\text { Growth in citrate media (Koser, } \\
\text { Simmons, and Christensen) }\end{array}$ & & & & & & & \\
\hline Growth in KCN media ........ & $6 / 32$ & $0 / 3$ & + & - & NT & $\stackrel{+}{\text { NT }}$ & - \\
\hline Growth in $0.4 \%(\mathrm{w} / \mathrm{v})$ selenite $\ldots$ & $0 / 23$ & $0 / 3$ & - & - & - & - & - \\
\hline Yellow pigment on nutrient agar & $4 / 30$ & $0 / 3$ & + & - & + & - & - \\
\hline $\begin{array}{l}\text { Yellow pigment on medium A of King } \\
\text { et al. (19) } \ldots \ldots \ldots \ldots \ldots \ldots \ldots\end{array}$ & $4 / 34$ & $0 / 3$ & + & - & - & - & - \\
\hline Pyocyanin, medium A, King et al. (19) & $0 / 34$ & $0 / 3$ & - & - & - & - & - \\
\hline Fluorescein, medium B, King et al. (19) & $0 / 34$ & $0 / 3$ & - & - & - & - & - \\
\hline $\begin{array}{l}\text { Intracellular accumulation of poly- } \\
\beta \text {-hydroxybutyrate } \ldots \ldots \ldots \ldots \ldots\end{array}$ & $35 / 35$ & $3 / 3$ & + & + & + & + & + \\
\hline Production of catalase $\ldots \ldots \ldots \ldots$ & $35 / 35$ & $3 / 3$ & + & + & + & + & + \\
\hline $\begin{array}{l}\text { Production of cytochrome oxidase } \\
\text { (Kovacs, 20) } \ldots \ldots \ldots \ldots \ldots \ldots\end{array}$ & $35 / 35$ & $3 / 3$ & + & + & + & + & + \\
\hline $\begin{array}{l}\text { Production of } \beta \text {-galactosidase } \ldots \ldots \\
\text { Amino-acid breakdown: }\end{array}$ & $19 / 27$ & $3 / 3$ & + & - & + & + & $d$ \\
\hline Arginine (M $\phi$ ller, 28) & $0 / 35$ & $0 / 3$ & - & - & - & - & - \\
\hline Lysine (M $\phi$ ller, 28) . . & $6 / 35$ & $1 / 3$ & - & - & + & + & $d$ \\
\hline Ornithine (M $\phi$ ller, 28) . . & $1 / 35$ & $0 / 3$ & - & - & - & + & - \\
\hline Arginine (Thornley, 45) & $0 / 35$ & $0 / 3$ & - & - & - & - & - \\
\hline Lysine (Richard, 36) ... & $23 / 23$ & $3 / 3$ & + & + & + & + & + \\
\hline Ornithine (Richard, 36) & $9 / 23$ & $3 / 3$ & - & + & - & + & $d$ \\
\hline Production of indole $\ldots \ldots \ldots \ldots$ & $0 / 35$ & $0 / 3$ & - & - & - & - & - \\
\hline $\begin{array}{l}\text { Production of } \mathrm{H}_{2} \mathrm{~S} \text { (lead acetate papers) } \\
\text { Production of } \mathrm{H}_{2} \mathrm{~S} \text { (triple-sugar-iron }\end{array}$ & $0 / 35$ & $0 / 3$ & - & - & - & - & - \\
\hline agar) $\ldots \ldots \ldots \ldots \ldots \ldots \ldots$ & $0 / 23$ & $0 / 3$ & - & - & - & - & - \\
\hline $\begin{array}{l}\text { Production of opalescence on egg- } \\
\text { yolk-agar } \ldots \ldots \ldots \ldots \ldots \ldots \ldots\end{array}$ & $27 / 35$ & $3 / 3$ & + & + & + & + & + \\
\hline Production of acetoin $\ldots \ldots \ldots$ & $0 / 35$ & $0 / 3$ & - & - & - & - & - \\
\hline Methyl red test . . . . . . & $0 / 35$ & $0 / 3$ & - & - & - & - & - \\
\hline Nitrate reduction, aerobically & $10 / 35$ & $2 / 3$ & + & - & - & + & $d$ \\
\hline Nitrate reduction, anaerobically ... & $12 / 35$ & $2 / 3$ & - & - & - & + & $d$ \\
\hline Nitrite reduction, aerobically $\ldots \ldots$. & $0 / 35$ & $0 / 3$ & - & - & - & - & - \\
\hline $\begin{array}{l}\text { Gas production in nitrate reduction } \\
\text { tests } \ldots \ldots \ldots \ldots \ldots \ldots \ldots \ldots\end{array}$ & $0 / 35$ & $0 / 3$ & - & - & - & - & - \\
\hline Liquefaction of gelatin . . . . . . . & $31 / 35$ & $3 / 3$ & + & + & + & + & + \\
\hline Liquefaction of serum $\ldots \ldots \ldots$ & $0 / 34$ & $0 / 3$ & - & - & NT & NT & - \\
\hline Hydrolysis of urea (Christensen) & $34 / 35$ & $3 / 3$ & + & + & + & + & + \\
\hline Hydrolysis of Tween $80 \ldots \ldots$. & $24 / 24$ & $3 / 3$ & + & + & + & + & + \\
\hline Hydrolysis of esculin .......... & $9 / 23$ & $3 / 3$ & - & + & + & - & $d$ \\
\hline Hydrolysis of tyrosine $\ldots \ldots \ldots \ldots$ & $24 / 24$ & $3 / 3$ & + & + & + & + & + \\
\hline Hydrolysis of $\operatorname{starch} \ldots \ldots \ldots \ldots$ & $0 / 35$ & $0 / 3$ & - & - & - & - & - \\
\hline Oxidation of gluconate $\ldots \ldots \ldots$ & $1 / 35$ & $0 / 3$ & - & - & - & - & - \\
\hline Utilization of malonate .. & $3 / 35$ & $3 / 3$ & - & - & - & - & - \\
\hline Deamination of phenylalanine ... & $0 / 35$ & $0 / 3$ & - & - & - & - & - \\
\hline Alkaline reaction in purple milk . . & $31 / 32$ & $3 / 3$ & + & + & + & + & + \\
\hline Casein digestion $\ldots \ldots \ldots \ldots \ldots$ & $32 / 35$ & $3 / 3$ & + & + & - & - & + \\
\hline Oxidative reaction in the Hugh and & & & & & & & \\
\hline Leifson (16) $\mathrm{O} / \mathrm{F}$ test $\ldots \ldots \ldots$ & $35 / 35$ & $3 / 3$ & + & + & + & + & + \\
\hline $\begin{array}{l}\text { In peptone water media, acid from } \\
\text { glucose } \ldots \ldots \ldots \ldots \ldots \ldots \ldots\end{array}$ & $21 / 35$ & $0 / 3$ & - & - & + & + & $d$ \\
\hline $\begin{array}{c}\text { In peptone water media, acid from } \\
\text { other carbohydrates } \ldots \ldots \ldots \ldots\end{array}$ & $0 / 24$ & $0 / 3$ & - & - & - & - & - \\
\hline
\end{tabular}


TABLE 3-Continued

\begin{tabular}{|c|c|c|c|c|c|c|c|}
\hline \multirow[b]{2}{*}{ Characters } & \multirow{2}{*}{$\begin{array}{c}\text { Field } \\
\text { strains }^{a}\end{array}$} & \multirow{2}{*}{$\begin{array}{c}\text { EO-1 } \\
\text { strains }\end{array}$} & \multicolumn{4}{|c|}{ NCTC strains } & \multirow{2}{*}{$\begin{array}{l}\text { Composite } \\
\text { result for } \\
P \text {. cepacia }\end{array}$} \\
\hline & & & 10661 & 10734 & 10743 & 10744 & \\
\hline \multicolumn{8}{|l|}{ On ammonium salt media, acid from: } \\
\hline Glucose $\ldots \ldots \ldots \ldots \ldots \ldots$ & $35 / 35$ & $3 / 3$ & + & + & + & + & + \\
\hline Arabinose $\ldots \ldots \ldots \ldots \ldots \ldots$ & $34 / 34$ & $3 / 3$ & + & + & + & + & + \\
\hline Cellobiose $\ldots \ldots \ldots \ldots \ldots \ldots$ & $20 / 20$ & $3 / 3$ & + & + & + & + & + \\
\hline Dulcitol . . . . . . . . . . . . . & $28 / 28$ & $3 / 3$ & NT & + & + & + & + \\
\hline Ethanol $\ldots \ldots \ldots \ldots \ldots \ldots$ & $6 / 24$ & $0 / 3$ & + & - & - & - & $d$ \\
\hline Galactose $\ldots \ldots \ldots \ldots \ldots \ldots$ & $20 / 20$ & $3 / 3$ & + & + & + & + & + \\
\hline Glycerol $\ldots \ldots \ldots \ldots \ldots \ldots$ & $20 / 20$ & $3 / 3$ & + & + & + & + & + \\
\hline Inositol $\ldots \ldots \ldots \ldots \ldots \ldots \ldots$ & $20 / 20$ & $3 / 3$ & + & + & + & + & + \\
\hline Inulin $\ldots \ldots \ldots \ldots$ & $0 / 20$ & $0 / 3$ & - & - & - & - & - \\
\hline Lactose $\ldots \ldots \ldots \ldots \ldots$ & $35 / 35$ & $3 / 3$ & + & + & + & + & + \\
\hline Fructose $\ldots \ldots \ldots \ldots \ldots \ldots$ & $20 / 20$ & $3 / 3$ & + & + & + & + & + \\
\hline Maltose $\ldots \ldots \ldots \ldots \ldots \ldots$ & $35 / 35$ & $3 / 3$ & + & + & + & + & + \\
\hline Mannitol $\ldots \ldots \ldots \ldots \ldots \ldots$ & $35 / 35$ & $3 / 3$ & + & + & NT & NT & + \\
\hline Mannose $\ldots \ldots \ldots \ldots \ldots \ldots$ & $20 / 20$ & $3 / 3$ & + & + & + & + & + \\
\hline Rhamnose ............ & $0 / 20$ & $0 / 3$ & - & - & - & - & - \\
\hline Salicin $\ldots \ldots \ldots \ldots \ldots$ & $33 / 35$ & $3 / 3$ & + & + & + & + & + \\
\hline Sorbitol . . . . . . . . . . & $35 / 35$ & $3 / 3$ & + & + & + & + & + \\
\hline Sucrose $\ldots \ldots \ldots \ldots \ldots \ldots$ & $28 / 35$ & $3 / 3$ & + & - & + & + & + \\
\hline Trehalose $\ldots \ldots \ldots \ldots \ldots \ldots$ & $20 / 20$ & $3 / 3$ & + & + & + & + & + \\
\hline Xylose $\ldots \ldots \ldots \ldots \ldots \ldots \ldots$ & $35 / 35$ & $3 / 3$ & + & + & + & + & + \\
\hline \multicolumn{8}{|l|}{ Acid production from $10 \%(\mathrm{w} / \mathrm{v})$} \\
\hline lactose agar & $33 / 35$ & $3 / 3$ & + & - & + & + & + \\
\hline
\end{tabular}

${ }^{a}$ Fractional entries are the number of strains positive out of the number of strains tested. NT, Not tested.

${ }^{b}$ Symbols;,+ 100 to $80 \%$ of strains positive; $d, 79$ to $21 \%$ of strains positive;,- 20 to $0 \%$ of strains positive.

Twenty-two strains were examined for arrangement of flagella by Plimmer and Paine's (34) staining technique, and two additional strains (NCTC 10661 and no. A32/69) were examined by electron microscopy. Deoxyribonucleic acid (DNA) base compositions, expressed as moles percent of guanine plus cytosine (\% GC) of the moles of total bases, were determined for these same two strains and for NCTC 10743 and 10744. DNA was extracted by the method of Marmur (25). The \% GC values were estimated from melting temperatures, $\left(\mathrm{T}_{\mathrm{m}}\right.$; Marmur and Doty, 26), determined in $0.1 \mathrm{M} \mathrm{NaCl}$ plus $0.01 \mathrm{M}$ phosphate buffer. The equation relating $\% \mathrm{GC}$ to $\mathrm{T}_{\mathbf{m}}$ for this buffer, derived from the general equation of Owen, Hill, and Lapage (30), was: \% GC $=2.362 \mathrm{~T}_{\mathbf{m}}$ 155.32.

Selected strains (see Results) were examined in the Cross-Infection Reference Laboratory, Colindale, for susceptibility to $P$. aeruginosa bacteriophages and agglutination with $P$. aeruginosa antisera and with a $P$. cepacia antiserum, supplied by courtesy of D. Taplin, Miami.

\section{RESULTS}

The results obtained with the field strains, EO-1 strains, and NCTC strains are listed in
Table 3 for most of the tests and in Table 4 for the carbon substrate utilization tests. Following the symbols used by Cowan and Steel $(5$; i.e. 100 to $80 \%$ of strains positive $=+; 79$ to $21 \%$ of strains positive $=d ; 20$ to $0 \%$ of strains positive $=-)$, the fractional entries in the first columns of results in Tables 3 and 4 reduce to 17 " $d$ " entries in the last columns out of a total of 112 tests. Of these 17 tests, 14 gave different results between the four NCTC strains; for example, aerobic reduction of nitrate was scored positive for 10 out of 35 strains tested, and 2 positive out of the three EO-1 strains, but NCTC 10661 and 10744 were positive whereas NCTC 10734 and 10743 were negative.

No further comment on most of the above results is required except the following points.

Viability. During the course of this work, a number of strains died. Loss of viability appeared erratic but has been noted also by Mackel (23) with reference to EO-1 strains. No loss of viability was found in the present series of strains when cultures were deliberately left at room temperature in the dark and periodically subcultured. 
TABLE 4. Results of the carbon substrate utilization test ${ }^{a}$

\begin{tabular}{|c|c|c|c|c|c|c|c|}
\hline \multirow[b]{2}{*}{ Substrate $^{b}$} & \multirow{2}{*}{$\begin{array}{c}\text { Field } \\
\text { strains }^{c}\end{array}$} & \multirow{2}{*}{$\begin{array}{c}\text { EO-1 } \\
\text { strains }^{c}\end{array}$} & \multicolumn{4}{|c|}{ NCTC strains } & \multirow{2}{*}{$\begin{array}{l}\text { Composite } \\
\text { result for } \\
P . \text { cepacia }^{d}\end{array}$} \\
\hline & & & 10661 & 10734 & 10743 & 10744 & \\
\hline$m$-Hydroxybenzoate $\ldots$. & $23 / 23$ & $2 / 3$ & + & + & + & + & + \\
\hline Pelargonate ......... & $16 / 23$ & $3 / 3$ & + & - & + & + & $d$ \\
\hline Hippurate $\ldots \ldots \ldots \ldots \ldots$ & $20 / 23$ & $1 / 3$ & + & + & + & + & + \\
\hline D-Pantothenate $\ldots \ldots \ldots$ & $19 / 23$ & $3 / 3$ & + & + & + & + & + \\
\hline Nicotinate ...... & $11 / 23$ & $3 / 3$ & - & + & - & + & $d$ \\
\hline Benzylamine & $24 / 23$ & $2 / 3$ & + & - & - & - & $d$ \\
\hline DL-Serine . . & $16 / 23$ & $3 / 3$ & + & + & + & + & $d$ \\
\hline D-Xylose . & $16 / 23$ & $3 / 3$ & + & - & + & + & $d$ \\
\hline Propionate & $29 / 23$ & $3 / 3$ & + & - & + & + & $d$ \\
\hline Glyoxylic acid . . . . . & $22 / 23$ & $3 / 3$ & + & + & + & + & + \\
\hline Glycolate $\ldots \ldots \ldots$ & $14 / 23$ & $2 / 3$ & + & + & + & + & $d$ \\
\hline
\end{tabular}

${ }^{a}$ Substrates utilized by all the strains examined: $\alpha$-ketoglutarate, pyruvate, succinate, acetate, fumarate, citrate, lactate, malonate, D-glucose, $n$-valerate, meso-inositol, L-valine, mannitol, betaine, sucrose, L-arginine, adipate, sarcosine, DL-tryptophan, L-hydroxyproline, DL-ornithine, DL-glutamic acid, L-histidine, L-asparagine, DL-aspartic acid, L-proline. Substrates not utilized by any of the strains examined: maleate, creatinine, urea, DL-methionine, catechol, oxalate.

D Substrates utilized by some of the strains examined.

$c$ Fractional entries are the number of strains positive out of the number of strains tested.

${ }^{d}$ Symbols:,+ 100 to $80 \%$ of strains positive; $d, 79$ to $21 \%$ of strains positive;,- 20 to $0 \%$ of strains positive.

Motility and flagella arrangement. Four strains (A106/70, A107/70, A117/70, A115/ 70) appeared nonmotile by the hanging-drop method, but further tests for motility were not made, as these strains were identified from their biochemical reactions as $P$. cepacia. Flagella staining by the method of Plimmer and Paine (34) showed a multitrichous polar arrangement, though in some cases there also appeared to be some lateral flagella. Two strains (NCTC 10661 and no. A32/69) were examined in the electron microscope by negative staining with $2 \%(\mathrm{w} / \mathrm{v})$ ammonium molybdate. The polar arrangement of the flagella was then clearly seen (Fig 1, 3). Most cells possessed two or three flagella, but occasionally up to 10 flagella per cell were observed (Fig. 2). In Fig. 2, there is an example of a flagellum probably winding back upon the cell and appearing to emerge laterally. The wavelengths of the extended flagella were 2.05 to $2.16 \mu \mathrm{m}$. Strain NCTC 10661 also showed peritrichous fimbriae (Fig. 3), though none were seen with A32/69. The fimbriae were 10 $\mathrm{nm}$ in diameter, which is in good agreement with the figure given by Tweedy, Park, and Hodgkiss (46), who also observed fimbriae on another strain of $P$. cepacia ( $P$. multivorans, NCIB 9691).

Pigmentation. No fluorescent pigments were observed. Burkholder (4), Morris and Roberts (29), Mackel (23), and Taplin et al. (44) reported that strains of $P$. cepacia produce various pigments: yellow, brown, red, violet, and purple. Stanier et al. (43), Jonsson (17), Gilardi (8), and Pickett and Pedersen (33) all recognized that pigmentation was variable and that nonpigmented strains could be found. A yellow pigment was produced by only four of the field strains and by NCTC 10661 and 10743 on nutrient agar. This yellow pigment did not diffuse into the surrounding agar, unlike that described by Hugh (15). No other pigments were observed.

Acid from carbohydrates. The outstanding property of $P$. cepacia is its nutritional versatility. This is shown by the very wide range of carbon substrates it can utilize (see below) and by its ability to produce acid from most carbohydrates tested. As with most pseudomonads, results are usually negative in peptone-water medium (J. J. S. Snell, Thesis, Fellowship of the Institute of Medical Laboratory Technology, 1970). Although 21 strains out of 35 tested scored as positive for acid from glucose in peptone-water medium (Table 3), the reaction obtained was weak, and no positive reactions were recorded for the other 18 carbohydrates tested (not shown in the table). On the ammonium salt medium of Smith, Gordon, and Clark (39), P. cepacia is readily recognized by production of acid from most of the wide range of carbohydrates tested: glucose, arabinose, cellobiose, dulcitol, galactose, glycerol, inositol, lactose, fructose, maltose, 



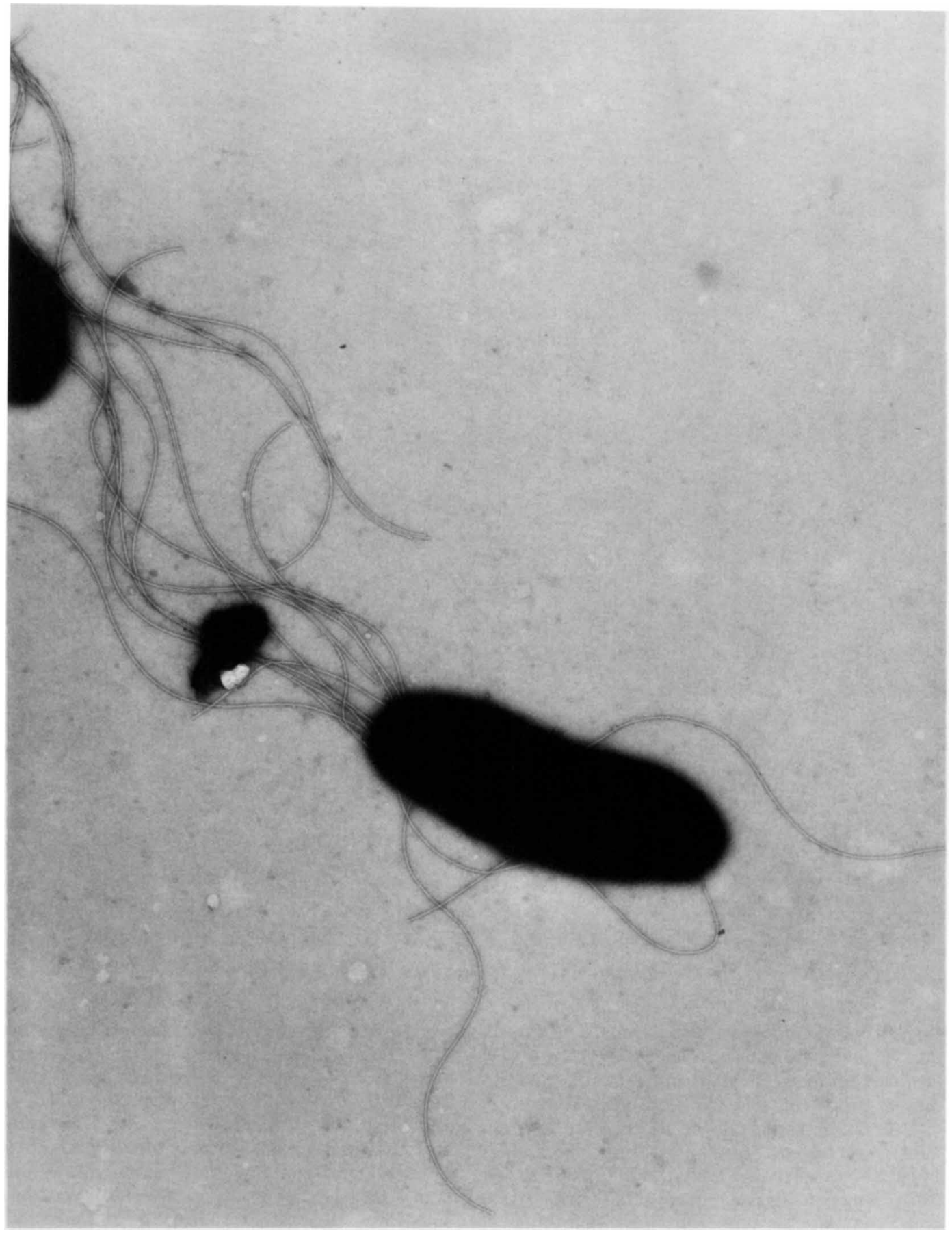

FIG. 2. Electron photomicrograph of field strain no. A32/69, showing 11 to 12 polar flagella and a few flagella apparently winding back upon the cell and appearing to emerge laterally. $\times 30,000$. 


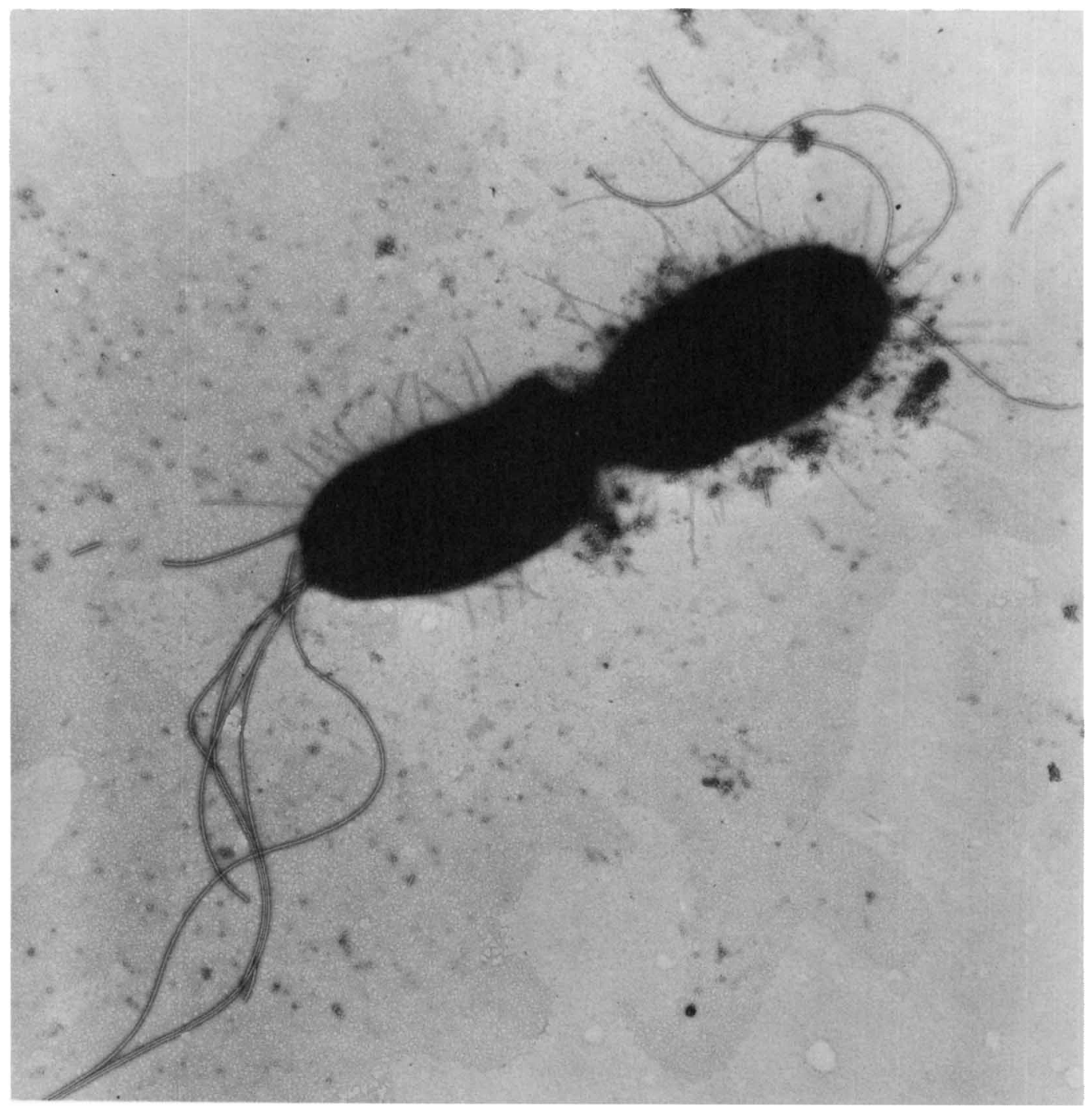

FIG. 3. Electron photomicrograph of NCTC 10661, showing polar flagella and fimbriae. $\times 30,000$.

mannitol, mannose, sorbitol, trehalose, xylose, and usually salicin and sucrose. Only a few strains produced acid from ethanol, and no strains produced acid from inulin or rhamnose.

Utilization tests. Of the 42 different carbon substrates tested, 36 were also used by Stanier et al. (43), who had tested NCTC 10661. For 34 of these substrates, our results for this strain were the same as those obtained by Stanier et al. In our laboratory, NCTC 10661 utilized pantothenate and valine, whereas Stanier et al. obtained negative results with these two substrates. Similarly, 33 substrates of the present set were used by Ballard et al. (1), who had tested NCTC 10743. Again, only two dis- crepant results were obtained: in our laboratory this strain utilized sarcosine and did not utilize benzylamine, whereas Ballard et al. (1) obtained the opposite results for NCTC 10743 and these two substrates. Therefore, our results are sufficiently well correlated with those of Stanier et al. and Ballard et al. to allow valid comparisons to be made. Of the 11 carbon substrates for which fractional entries are made in Table 4, one (glyoxylic acid) was not used by Stanier et al., whereas seven (hippurate, nicotinate, benzylamine, DL-serine, D-xylose, propionate, and glycolate) also gave variable results with the 19 strains of $P$. cepacia characterized by Stanier et al., although only one of these 
(benzylamine) gave variable results with the 18 strains later characterized by Ballard et al.

DNA base compositions. The $\% \mathrm{GC}$ values determined were as follows: NCTC 10661, 69.3 ; A32/69, 69.5; NCTC 10743, 69.2; NCTC $10744,69.0$. These values can be considered the same, within the limits of experimental error ( $\pm 0.4 \% \mathrm{GC}$, Owen et al., 30 ). The values for NCTC 10661 and 10743 are a little higher than those given by Mandel (24) and Ballard et al. (1) for these same two strains: $+2.5 \%$ GC and $+1.4 \%$ GC, respectively. However, their determinations were made by a different technique (buoyant density), and differences of this magnitude from one laboratory to another are not uncommon $(13,14)$.

Phage typing. None of the strains tested were susceptible to any of the $P$. aeruginosa bacteriophages in use at Colindale.

Serotyping. Basset et al. (2) reported that the strains isolated from the outbreak they described gave a cross-reaction with $P$. aeruginosa antiserum 13 (47). Other strains from the present series did not give this cross-section. Only four out of 13 strains tested agglutinated in a slide test with a $P$. cepacia antiserum (positive: A73/66, A46/69, A104/69, A98/70; negative: 10661, A66/69, A67/69, A102/69, A 103/69, A107/69, A61/70, A62/70, A99/70).

\section{DISCUSSION}

The characteristics of the 35 field strains and the three EO-1 strains agree with those found for the type strain of $P$. cepacia (NCTC 10743), the two NCTC strains of $P$. multivorans (NCTC 10661 and 10734) and the type strain of $P$. kingii (NCTC 10744). When different results were obtained between the field and NCTC strains, in most cases either the NCTC strains also differed from each other or the results were for tests which Stanier et al. (43) also found to be variable for this species. The description of $P$. cepacia, as amended by Stanier et al. (43) and Ballard et al. (1), lays particular emphasis on the very wide range of carbon substrates this species is able to utilize. In this respect, agreement was very close between the field strains, the NCTC strains, and with the published data of Stanier et al. and Ballard et al.

The synonymy of $P$. cepacia Burkholder 1950 and $P$. multivorans Stanier et al. 1966 was established by Ballard et al. (1) on the basis of indistinguishable patterns of test results and of similar levels of molecular homology as shown by in vitro DNA-DNA molecular hybridization techniques. In addition to this synonymy, we propose that $P$. kingii also be considered a synonym of $P$. cepacia, the latter name having priority. This proposal is also made on the basis of indistinguishable patterns of tests results. The only differences between the type strain of P. cepacia (NCTC 10743) and the type strain of P. kingii (NCTC 10744) are given in Table 5. Of the seven tests listed, five gave differences between the other two NCTC strains of $P$. cepacia (P. multivorans NCTC 10661 and 10734). With the remaining two tests, the three EO-1 strains gave different results from the type strain of $P$. kingii.

The in vitro molecular hybridization experiments of Ballard et al. (1) also established genetic relationships between $P$. cepacia and several other pseudomonads: $P$. pseudomallei, $P$. mallei, and the phytopathogenic species $P$. marginata (synonym: $P$. alliicola) and $P$. caryophylli. These relationships were also reflected in the nutritional versatility of all five species ( $P$. cepacia being the most versatile), and all five accumulate poly- $\beta$-hydroxybutyrate intracellularly. Ballard et al. (1) consider these five species to be a "species cluster," which they provisionally call the "pseudomallei group."

TABLE 5. Differences between the type strains of Pseudomonas cepacia and of $P$. kingii, compared with data for the field and other NCTC strains

\begin{tabular}{|c|c|c|c|c|c|c|}
\hline Characters & $\begin{array}{c}P . \text { cepacia } \\
10743\end{array}$ & $\begin{array}{c}\text { P. kingii } \\
10744\end{array}$ & 10661 & 10734 & $\begin{array}{l}\text { Field } \\
\text { strains }\end{array}$ & $\begin{array}{c}\text { EO-1 } \\
\text { strains }\end{array}$ \\
\hline $\begin{array}{l}\text { Biochemical tests } \\
\text { Yellow pigment on nutrient agar } \ldots \ldots \ldots \\
\text { Breakdown of ornithine }(\mathrm{M} \phi l \text { ller, } 28) \ldots \ldots \\
\text { Breakdown of ornithine (Richard, } 36) \ldots \\
\text { Nitrate reduction, aerobically } \ldots \ldots \ldots \ldots \\
\text { Nitrate reduction, anaerobically } \ldots \ldots \ldots \\
\text { Hydrolysis of esculin } \ldots \ldots \ldots \ldots \ldots \ldots \ldots \\
\text { Utilization tests } \\
\text { Nicotinate } \ldots \ldots \ldots \ldots \ldots \ldots\end{array}$ & $\begin{array}{l}+ \\
- \\
- \\
- \\
- \\
+ \\
-\end{array}$ & $\begin{array}{l}- \\
+ \\
+ \\
+ \\
+ \\
- \\
+\end{array}$ & $\begin{array}{l}+ \\
- \\
- \\
+ \\
-\end{array}$ & $\begin{array}{l}- \\
- \\
+ \\
- \\
- \\
+ \\
+\end{array}$ & $\begin{array}{r}4 / 30 \\
1 / 35 \\
9 / 23 \\
10 / 35 \\
12 / 35 \\
9 / 23 \\
11 / 23\end{array}$ & $\begin{array}{l}0 / 3 \\
0 / 3 \\
3 / 3 \\
2 / 3 \\
2 / 3 \\
3 / 3 \\
3 / 3\end{array}$ \\
\hline
\end{tabular}


This grouping together of species within the genus Pseudomonas appears realistic, for there are not many properties which can reliably separate, for identification purposes, $P$. cepacia from $P$. pseudomallei or $P$. mallei, although $P$. cepacia is very different from the other pseudomonads likely to be met in clinical circumstances. Table 6 summarizes the data available to us to differentiate $P$. cepacia from the above two species and also from $P$. aeruginosa, $P$. fluorescens, $P$. stutzeri, and $P$. maltophilia. The table was compiled from Lapage et al. (22), Snell (Thesis, Fellowship of the Institute of Medical Laboratory Technology, 1970), results of this present study, and NCTC records. Denitrification capacities reported for $P$. pseudomallei by Redfearn, Palleroni, and Stanier (35) and for $P$. aeruginosa and $P$. fluorescens by Stanier et al. (43) are greater than we give for these species in Table 6. However, Stanier's group uses a different technique from the one employed by us (see Materials and Methods).
The only consistent differences between $P$. cepacia and $P$. pseudomallei are breakdown of arginine (Moller [28] or Thornley [45]; negative for $P$. cepacia, positive for $P$. pseudomallei) and of lysine (Richard's method [36]; positive for $P$. cepacia, negative for $P$. pseudomallei) although there are several " $d$ " entries in Table 5 which should also assist identification. In the hope of improving the separation of these two species, the wider range of carbohydrates shown in Table 3 for P. cepacia (acid production from carbohydrates in the ammonium salt medium of Smith et al. [39]) was also used with $P$. pseudomallei strains. However, the pattern of results obtained for $P$. pseudomallei was the same as that given by $P$. cepacia (see Table 3). Not recorded in Table 6 is the very characteristic colonial appearance of $P$. pseudomallei illustrated by Lapage et al. (22), which is not shown by $P$. cepacia.

Carbon substrate utilization results have not been included in Table 6 , because they are unlikely to be used in hospital laboratory

TABLE 6. Differentiation of Pseudomonas cepacia

\begin{tabular}{|c|c|c|c|c|c|c|c|}
\hline Character & $\begin{array}{l}P . \text { cepacia } \\
(41)^{a}\end{array}$ & $\begin{array}{c}\text { P. pseudo- } \\
\text { mallei } \\
\text { (11) }\end{array}$ & $\begin{array}{l}\text { P. mallei } \\
\text { (8) }\end{array}$ & $\begin{array}{l}P \text {. aeru- } \\
\text { ginosa } \\
\text { (13) }\end{array}$ & $\begin{array}{l}P . \text { fluo- } \\
\text { rescens } \\
\quad(4)\end{array}$ & $\begin{array}{c}\text { P. stut- } \\
\text { zeri } \\
(8)\end{array}$ & $\begin{array}{c}\text { P. malto- } \\
\text { philia } \\
\text { (3) }\end{array}$ \\
\hline Number of flagella per cell . . . . . . . . . & $>1$ & $>1$ & 0 & 1 & $>1$ & 1 & $>1$ \\
\hline Oxidase $\ldots \ldots \ldots \ldots \ldots \ldots \ldots$ & + & + & $d^{b}$ & + & + & + & $d$ \\
\hline Growth at $5 \mathrm{C} \ldots \ldots \ldots \ldots$ & - & - & - & - & + & $d$ & - \\
\hline Citrate utilization (Christensen) .. & + & + & $d$ & + & + & + & + \\
\hline Citrate utilization (Koser or Simmons) & + & + & - & + & + & + & - \\
\hline Nitrate reduction $\ldots \ldots \ldots \ldots \ldots$ & $d$ & + & + & + & $d$ & + & + \\
\hline Nitrate reduction, with gas production & - & - & - & $d$ & - & + & - \\
\hline Breakdown of arginine (Møller, 28, and & & & & & & & \\
\hline Thornley, 45) $\ldots \ldots \ldots \ldots \ldots$ & - & + & + & + & + & $d$ & - \\
\hline Breakdown of lysine (M $\phi$ ller, 28). & $d$ & - & - & - & - & - & + \\
\hline Breakdown of lysine (Richard, 36) & + & - & $\mathrm{NT}^{b}$ & NT & NT & NT & NT \\
\hline Breakdown of ornithine (Richard, 36) .. & $d$ & - & NT & NT & NT & NT & NT \\
\hline Gelatin liquefaction ............. & + & + & $d$ & + & + & - & + \\
\hline Accumulation of poly- $\beta$-hydroxybuty- & & & & & & & \\
\hline rate $\ldots \ldots \ldots \ldots \ldots \ldots$ & + & + & + & - & - & - & - \\
\hline Starch hydrolysis . . . . . . . . . . & - & $d$ & - & - & - & + & - \\
\hline $\begin{array}{l}\text { Tween } 80 \text { hydrolysis } \ldots \ldots \ldots \ldots \ldots \\
\text { Acid produced from }{ }^{c}\end{array}$ & + & + & $d$ & + & - & NT & - \\
\hline Glucose ........ & + & + & + & + & + & + & - \\
\hline Dulcitol $\ldots \ldots \ldots \ldots \ldots \ldots \ldots$ & + & + & - & - & - & - & - \\
\hline Maltose ................ & + & + & $d$ & - & - & - & + \\
\hline 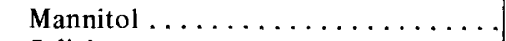 & + & + & + & + & + & $d$ & - \\
\hline Salicin $\ldots \ldots \ldots \ldots \ldots \ldots \ldots$ & + & - & - & - & - & - & - \\
\hline Sorbitol $\ldots \ldots \ldots \ldots \ldots \ldots \ldots$ & + & + & + & - & $d$ & - & - \\
\hline Xylose $\ldots \ldots \ldots \ldots \ldots \ldots \ldots$ & + & + & - & + & + & NT & - \\
\hline Acid produced from $10 \%$ lactose agar .. & + & + & + & $d$ & + & - & - \\
\hline
\end{tabular}

${ }^{a}$ Figures in parentheses following species names indicate number of strains examined.

$b$ Abbreviations: NT, not tested; $d$, variable results.

$c$ On the ammonium salt media of Smith et al. (39). 
routines. However, even with these tests added, the differentiation of $P$. cepacia and $P$. pseudomallei is not much improved. Our results on 30 and 11 strains, respectively, were that $P$. cepacia utilizes 30 out of 43 substrates tested, and 29 of these 30 are utilized also by $P$. pseudomallei.

The increasing number of reports in the literature of the occurrence of $P$. cepacia in hospital infections, including the episodes reported here, indicates that this organism is creating serious problems. The common sequence of events appears to be contamination, possibly from water supplies, of disinfectant solutions. This is followed by infection of the patients, frequently mediated by the use of indwelling catheters. This sequence of events emphasizes the need for proper supervision of the preparation and use of disinfectants.

\section{ACKNOWLEDGMENTS}

We thank D. C. Jenkins, E. Lockey, R. L. McCorry, I. Phillips, P. H. A. Sneath, D. C. E. Speller, K. J. Stokes, and R. E. Weaver for sending us strains for identification and comparison, and R. L. McCorry and E. Lockey for permission to publish their clinical information. We are also grateful to Ann Field for the electron microscopy and to D. C. J. Bassett for serotyping and phage typing the strains.

\section{LITERATURE CITED}

1. Ballard, R. W., N. J. Palleroni, M. Doudoroff, R. Y. Stanier, and M. Mandel. 1970. Taxonomy of the aerobic pseudomonads: Pseudomonas cepacia, $P$. marginata, $P$. allicola and $P$. caryophylli. $J$. Gen. Microbiol. 60: 199-214.

2. Bassett, D. C. J., K. J. Stokes, and W. R. G. Thomas. 1970. Wound infection with Pseudomonas multivorans. Lancet 1:1188-1191.

3. Burdon, D. W., and J. C. Whitby. 1967. Contamination of hospital disinfectants with Pseudomonas species. Brit. Med. J. ii: 153-155.

4. Burkholder, W. H. 1950. Sour skin, a bacterial rot of onion bulbs. Phytopathology 40:115-117.

5. Cowan, S. T., and K. J. Steel. 1965. Manual for the identification of medical bacteria. University Press, Cambridge.

6. Crosby, N. T. 1967. The determination of nitrite in water using Cleve's acid, 1-naphthylamine-7sulphonic acid. J. Soc. Water Treatment Exam. 16:51-55.

7. Daily, R. H., and E. J. Benner. 1968. Necrotizing pneumonitis due to the pseudomonad "Eugonic Oxidizer-group 1". N. Engl. J. Med. 279:361-362.

8. Gilardi, G. L. 1970. Characterization of EO-1 strains ( $P_{\text {seudomonas }}$ king ii) isolated from clinical specimens and the hospital environment. Appl. Microbiol. 20: 521-522.
9. Gilardi, G. L. 1971. Characterization of Pseudomonas species isolated from clinical specimens. Appl. Microbiol. 21:414-419.

10. Gordon, R. E., and M. M. Smith, 1955. Rapidly growing, acid fast bacteria. II. Species' description of Mycobacterium fortuitum Cruz. J. Bacteriol. 69:502-507.

11. Graber, C. D., L. P. Jervey, W. E. Ostrander, L. H. Salley, and R. E. Weaver. 1968. Endocarditis due to a lanthanic, unclassified gram-negative bacterium (group IVd). Amer. J. Clin. Pathol. 49:220-223.

12. Hardy, P. C., G. M. Ederer, and J. M. Matsen. 1970. Contamination of commercially packed urinary catheter kits with the pseudomonad EO-1. N. Engl. J. Med. 282:33-35.

13. Hill, L. R., R. H. Leach, and B. E. Andrews. 1970. The value of DNA base composition determinations in the classification of some atypical mycoplasmas. Spisy Prirodoved. Fak. Univ. Brne Ser. K 47:79-83.

14. Hill, L. R., J. J. S. Snell, and S. P. Lapage. 1970. Identification and characterization of Bacteroides corrodens. J. Med. Microbiol. 3:483-491.

15. Hugh, R. 1970. A practical approach to the identification of certain nonfermentative gramnegative rods encountered in clinical specimens. Pub. Health Lab. 28:168-187.

16. Hugh, R., and E. Leifson. 1953. The taxonomic significance of fermentative versus oxidative metabolism of carbohydrates by various gram negative bacteria. J. Bacteriol. 66:24-26.

17. Jonsson, V. 1970. Proposal of a new species Pseudomonas kingii. Int. J. Syst. Bacteriol. 20:255-257.

18. King, E. O. 1964. The identification of unusual pathogenic Gram negative bacteria. National Communicable Disease Center, Atlanta.

19. King, E. O., M. K. Ward, and D. E. Raney. 1954. Two simple media for the demonstration of pyocyanin and fluorescin. J. Lab. Clin. Med. 44:301-307.

20. Kovacs, N. 1956. Identification of Pseudomonas pyocyanea by the oxidase reaction. Nature (London) 178:703.

21. Lapage, S. P., and S. Bascomb. 1968. Use of selenite reduction in bacterial classification. $\mathbf{J}$. Appl. Bacteriol. 31: 568-580.

22. Lapage, S. P., L. R. Hill, and J. D. Reeve. 1968. Pseudomonas stutzeri in pathological material. J. Med. Microbiol. 1:195-202.

23. Mackel, D. C. 1970. Contamination of disposable catheter kits with EO-1. N. Engl. J. Med. 282:752-753.

24. Mandel, M. 1966. Deoxyribonucleic acid base composition in the genus Pseudomonas. J. Gen. Microbiol. 43:273-292.

25. Marmur, J. 1961. A procedure for the isolation of deoxyribonucleic acid from microorganisms. J. Mol. Biol. 3:208-218.

26. Marmur, J., and P. Doty. 1962. Determination of the base composition of deoxyribonucleic acid from its thermal denaturation temperature. J. Mol. Biol. 5:109-118. 
27. Mitchell, R. G., and A. C. Hayward. 1966. Postoperative urinary-tract infections caused by contaminated irrigating fluid. Lancet 1:793-795.

28. Møller, V. 1955. Simplified tests for some amino acid decarboxylases and for the arginine dihydrolase system. Acta Pathol. Microbiol. Scand. 36:158-172.

29. Morris, M. B., and J. B. Roberts. 1959. A group of pseudomonads able to synthesize poly- $\beta$-hydroxybutyric acid. Nature (London) 183:1538-1539.

30. Owen, R. J., L. R. Hill, and S. P. Lapage. 1969. Determination of DNA base compositions from melting profiles in dilute buffers. Biopolymers 7:503-516.

31. Owens, J. D., and R. M. Keddie. 1968. A note on the vitamin requirements of some coryneform bacteria from soil and herbage. J. Appl. Bacteriol. 31:344-348.

32. Phillips, I., S. Eykyn, M. A. Curtis, and J. J. S. Snell. 1971. Pseudomonas cepacia (multivorans) septicaemia in an intensive-care unit. Lancet 1:375-377.

33. Pickett, M. J., and M. M. Pedersen. 1970. Characterization of saccharolytic nonfermentative bacteria associated with man. Can J. Microbiol. 16:351-362.

34. Plimmer, H. G., and S. G. Paine. 1921. A new method for the staining of bacterial flagella. J. Pathol. Bacteriol. 24:286-288.

35. Redfearn, M. S., N. J. Palleroni, and R. Y. Stanier. 1966. A comparative study of Pseudomonas pseudomallei and Bacillus mallei. J. Gen. Microbiol. 43:293-313.

36. Richard, C. 1968. Techniques rapides de recherche des lysine-decarboxylase, ornithinedecarboxylase et arginine-dihydrolase dans les genres Pseudomonas, Alcaligenes et Moraxella. Ann. Inst. Pasteur 114:425-430.

37. Sands, D. C., M. N. Schroth, and D. C. Hildebrand. 1970. Taxonomy of phytopathogenic pseudomonads. J. Bacteriol. 101:9-23.
38. Sierra, G. 1957. A simple method for the detection of lipolytic activity of micro-organisms and some observations on the influence of the contact between cells and fatty substrates. Antonie van Leeuwenhoek J. Microbiol. Serol. 23:15-22.

39. Smith, N. R., R. E. Gordon, and F. E. Clark. 1952. Aerobic spore forming bacteria. Agriculture Monograph No. 16. U.S. Department of Agriculture.

40. Sneath, P. H. A. 1956. Cultural and biochemical characteristics of the genus Chromobacterium. J. Gen. Microbiol. 15:70-98.

41. Sneath, P. H. A. 1960 . A study of the bacterial genus Chromobacterium. lowa State Coll. J. Sci. 34:243-500.

42. Speller, D. C. E., M. E. Stephens, and A. C. Viant. 1971. Hospital infection by Pseudomonas cepacia. Lancet 1:798-799.

43. Stanier, R. Y., N. J. Palleroni, and M. Doudoroff. 1966. The aerobic pseudomonads: a taxonomic study. J. Gen Microbiol. 43:159-271.

44. Taplin, D., D. C. J. Bassett, and P. M. Mertz. 1971. Foot lesions associated with Pseudomonas cepacia. Lancet 2:568-571.

45. Thornley, M. J. 1960. The differentiation of Pseudomonas from other Gram negative bacteria on the basis of arginine metabolism. J. Appl. Bacteriol. 23:37-52.

46. Tweedy. J. M., R. W. A. Park, and W. Hodgkiss. 1968. Evidence for the presence of fimbriae (pili) on vibrio species. J. Gen. Microbiol. 51:235-244.

47. Véron, M. 1961. Sur l'agglutination de Pseudomonas aeruginosa $0: 2$ et $0: 5$. Ann. Inst. Pasteur 101:456-460.

48. Yabuuchi, E., N. Miyajima, H. Hotta, A. Ohyama, and N. Tanaka. 1970. Pseudomonas cepacia from blood of a burn patient. Med. J. Osaka Univ. 21:1-6. 